$\underline{\text { Review }}$

\title{
Evaluation of in-vivo and in-vitro microbiological methods for testing the efficacy of parenteral antibiotics: A Review
}

\author{
BAG Chathuranga $^{1}$, DMBT Dissanayake $^{2}, \mathrm{SSN}_{\text {Fernando }}^{2}, \mathrm{CA}$ Wanigatunge $^{3}$
}

Sri Lankan Journal of Infectious Diseases 2020 Vol.10(2):86-97

DOI: http://dx.doi.org/10.4038/sljid.v10i2.8275

\begin{abstract}
Antibiotics are available as innovators and generics. An innovator or branded drug is a medicine that is discovered, developed and marketed by a pharmaceutical company which also holds the patent for that drug. Generics only become available after the patent on the innovator expires. Generic drugs are required to have the same active ingredient, strength, dosage form, and route of administration as the innovator product. Generics should be bioequivalent to the innovator and when used, should have the same efficacy and safety profile. This is crucial for parenteral antibiotics because according to the World Health Organization and U.S. Food and Drug Administration criteria, parenteral generic products do not need to provide evidence for in-vivo bioavailability or bioequivalence before they can be marketed. Published evidence shows that there is a disparity in the efficacy of different generic antibiotic products. In-vitro microbiological methods of efficacy testing have been recognized as a standardized and cost-effective approach to clarify doubts regarding the efficacy of generic parenteral antibiotics. However, in-vitro methods used alone, might not be a good measurement of antibiotic efficacy as several studies have shown disparities between in-vitro and in-vivo efficacy of parenteral antibiotics.
\end{abstract}

Key words: efficacy, generic drugs, innovator products, parenteral antibiotics, in-vitro

\section{Introduction}

Antibiotics, the choice of treatment for bacterial infections, have greatly reduced illness and death from infectious diseases and helped to improve life expectancy. Antibiotics have become one of the most frequently used medicinal drugs for both treatment and prophylaxis. The global antibiotic consumption has increased by $65 \%$, i.e. from 21.1 to 34.8 billion defined daily doses, between

${ }^{I}$ Department of Medical Laboratory Sciences, Faculty of Allied Health Sciences, University of Sri Jayewardenepura, Sri Lanka

${ }^{2}$ Department of Microbiology, Faculty of Medical Sciences, University of Sri Jayewardenepura, Sri Lanka ${ }^{3}$ Department of Pharmacology, Faculty of Medical Sciences, University of Sri Jayewardenepura, Sri Lanka Address for correspondence: Mr Gayashan Chathuranga, Department of Medical Laboratory Sciences, Faculty of Allied Health Sciences, University of Sri Jayewardenepura, Sri Lanka Telephone: +94759709448

E-mail:chathuranga@sjp.ac.lk (D)https://orcid.org/0000-0001-5194-988X

Received 19 November 2019 and revised version accepted 17 July 2020

(c) (†) use, distribution, and reproduction in any medium, provided the original author and source are credited. 
2000 and 2015. This was primarily driven by increased consumption in lower and middle income countries. ${ }^{1}$

Antibiotics are available both as innovator products and generics. An innovator product is a medicine that is discovered, developed and marketed by a pharmaceutical company which also holds the patent for that drug, while a generic is a product that is comparable to an innovator/branded/reference listed product in dosage, form, strength, route of administration, quality and performance characteristics and intended use. ${ }^{2}$ Generics only become available after the patent and/or data protection period expires on an innovator drug. Generic products are typically sold at lower costs, primarily because they do not have to bear expenses for drug discovery studies and also as a result of the competition in the market. Introduction of generics have resulted in significant reduction in prices of antibiotics. ${ }^{3}$

A major concern for healthcare delivery systems in developing countries is finding ways to limit increasing costs without compromising quality. To address this issue, their governments have encouraged the use of generic medicines. Medical practitioners in Sri Lanka are legally required to write the generic name of the medicine in every prescription. ${ }^{4}$ The prescriber may also write a brand name of the drug in addition to the generic name if desired. To effectively implement this policy, the generic drugs must be bioequivalent and pharmaceutically equivalent to the innovator/ branded counterpart. To be pharmaceutically equivalent, a similar dosage form of a generic product must contain identical amounts of active ingredients and be identical in strength/concentration to the innovator. A generic product is considered bioequivalent to an innovator when there is no significant difference between the generic and the innovator in the rate and extent to which the active ingredient becomes available at the site of drug action when administered at the same dose under similar conditions. ${ }^{5}$

In most low and middle-income countries such as Sri Lanka, infrastructure facilities related to drug registration are not optimal. Laboratory facilities are not adequate to provide complete quality checks of generic products and are mostly limited to paper-based assessments at registration and when complaints are received. This factor might influence the medical practitioners in the selection of generic products for treatment. A survey conducted among physicians in the United States of America revealed that the majority showed concern about the quality and efficacy of generic drugs and this perception was a barrier to increase their use of generic drugs. ${ }^{6}$ Evidence based studies are required in developing countries to ensure that generics have the same efficacy and safety profile as innovator drugs which will then promote the prescription of generics to achieve the expected economic benefits. This general review was conducted to determine whether the existing literature supports the use of generic parenteral antibiotics and to analyze published data regarding the in-vitro assessment of parenteral antibiotic efficacy by microbiological methods.

\section{Search strategy and selection of publications}

As this is a general review, a broad search strategy was adopted. A literature search was performed in MEDLINE and PUBMED, without limits for publication date but with limits for English language publications. All articles published until August 2018 that were within the inclusion criteria were selected. The following keywords were used in various combinations for the literature search: 'generics,' 'generic products,' 'parenteral antibiotics,' 'brand name antibiotics,' 'in-vitro 
efficacy testing,' 'microbiological methods,' 'minimal inhibitory concentration,' 'efficacy' and 'innovator products'.

\section{Selection of appropriate studies}

All authors independently reviewed abstracts to identify articles that required a full-text review. Final decision regarding the inclusion of an article was reached through consensus. Reference lists of the selected articles were searched for additional articles.

Two main categories of published data were selected for the review.

1. Studies that assessed therapeutic equivalence or non-equivalence of generic and branded drugs.

2. Comparative microbiological studies of the efficacy of parenteral antibiotics

Studies were selected, if they reported on a comparative assessment of at least two different commercial products of the same parenteral antibiotic. Comparative evaluation had to be done by microbiological methods.

Qualitative analyses of efficacy, clinical trials and pharmaco-economic evaluations were excluded.

\section{Results}

We identified 21 original research articles that fall under the above two categories for detailed analysis: There were 16 studies where the efficacy of parenteral antibiotics was compared by invitro methods. Of these, five (5) assessed both in-vivo and the in-vitro efficacy simultaneously. Two (2) studies showed therapeutic failures when using generic antibiotics and three (3) studies focused on increased antimicrobial resistance following the use of generic antibiotics.

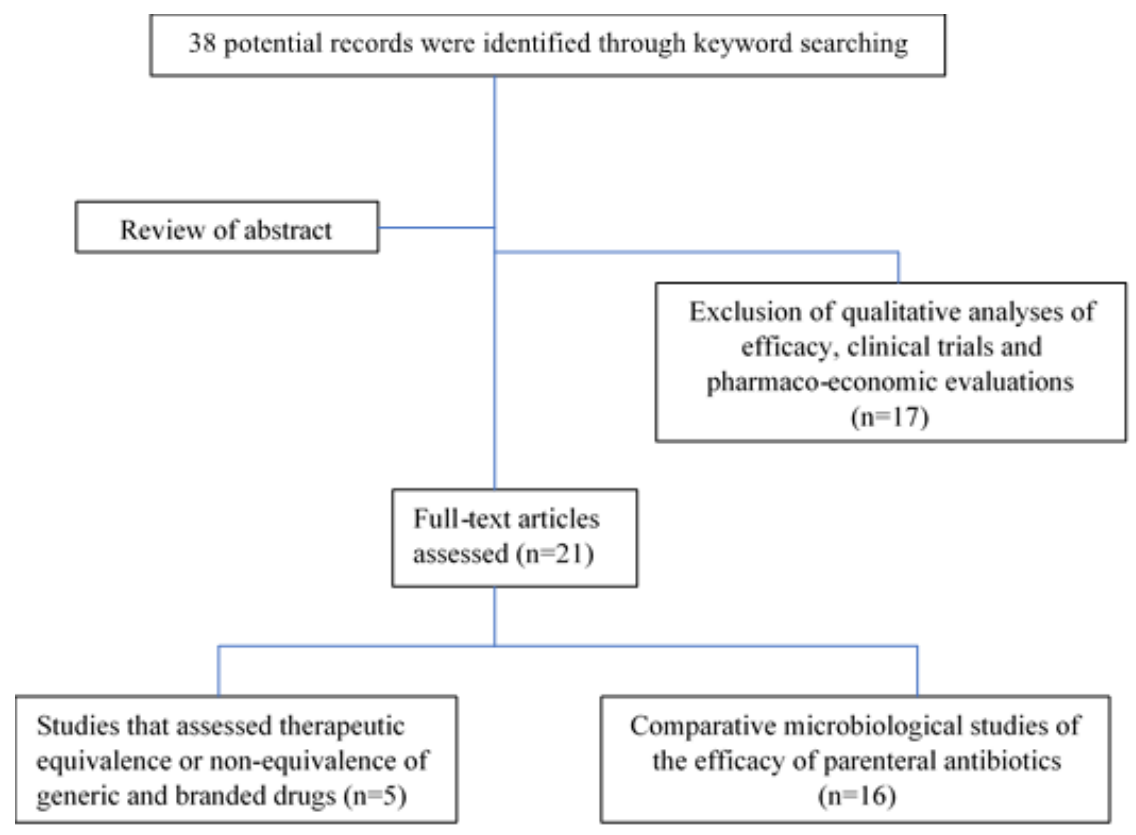

Figure 1: Summarized search strategy 


\section{Evidence for therapeutic failures and increased antimicrobial resistance following the use of generic antibiotics.}

Therapeutic failures as a result of using suboptimal antibacterial therapy will lead to increased morbidity, mortality and dissatisfaction among prescribers regarding the generic antibiotics. Galleli et $\mathrm{al}^{7}$ reported a case series in which therapeutic failures were observed during treatment with generic products of ciprofloxacin and levofloxacin. Switching from generics to innovator formulations resulted in clinical improvement. The findings suggest that the use of generic drugs could lead to increased duration of the disease or therapeutic failure. In another case study, a patient developed methicillin resistant Staphylococcus aureus (MRSA) bacteremia following liver transplantation and was given a generic vancomycin product for 10 days without improvement of the condition. ${ }^{8}$ When the patient was switched to an identical regimen using the innovator product, clinical improvement was rapidly evident with sterility in blood cultures taken 24 hours after the infusion of the innovator product. ${ }^{8}$

Use of commercial products with low level of antibacterial efficacy results in therapeutic failures and might also promote the selection of resistant bacterial subpopulations. ${ }^{9}$ Such resistant bacterial infections would require broad spectrum antibiotics. An increase in the demand for broad spectrum antibiotics was noted after the introduction of generic products to the German pharmaceutical market after the year 2000. ${ }^{10}$ Generic norfloxacin was introduced to the German market in 1999 and the resistance rate increased by nearly 3 fold (26.4\% in 2007) after the introduction of generics. ${ }^{10}$ In Denmark, a significant increase was observed in ciprofloxacin resistance in urine isolates of Escherichia coli after the introduction of generic ciprofloxacin. ${ }^{3}$ These data show the importance of establishing monitoring mechanisms to evaluate the quality of generic drugs.

The situation becomes more critical for parenteral antibiotics as both WHO and FDA criteria do not require parenteral generic products to provide evidence of in-vivo bioavailability or bioequivalence for approval. ${ }^{11,12}$ These authorities assume that the two products are therapeutically equivalent if they are pharmaceutically equivalent. This criterion of assessing therapeutic equivalence of generic drugs has been challenged by various researchers. ${ }^{7,8}$ Quality and efficacy testing therefore play a vital role to clear doubts among patients, healthcare personnel and prescribers regarding parenteral generic antibiotics.

\section{Assessment of the efficacy of generic parenteral products by microbiological methods}

Antibiotic efficacy can be assessed by different methodologies including analytical chemistry, invitro susceptibility studies, in-vivo animal experiments, and clinical studies in humans. ${ }^{13}$ In-vitro methods of efficacy testing have been recognized as a standardized and cost effective approach and thus recommended for parenteral antibiotics as their bioequivalence is considered as "selfevident". ${ }^{14}$

Various in-vitro techniques have been used to compare the efficacy of different brands of antibiotics. Of the 16 studies considered in this review, Minimal Inhibitory Concentration (MIC) was used for efficacy testing in 13 studies. MIC is the lowest concentration of an antimicrobial agent that prevents visible growth of a microorganism in an agar or broth dilution susceptibility test. ${ }^{15}$ Seven studies $(n=7)$ used Minimal Bactericidal Concentration (MBC) alongside the MIC 
for efficacy testing. MBC is the minimal concentration of drug needed to kill most ( $\geq 99.9 \%)$ of the viable organisms after incubation for a fixed length of time (generally 24 hours) under a given set of conditions. ${ }^{16}$ One study used MBC on its own without the MIC. Agar diffusion technique was used in three studies to assess efficacy instead of MIC or MBC. A summary of the in-vitro studies conducted to test the efficacy of parenteral antibiotics is given in Table 1.

In some studies $(n=5)$, in-vitro efficacy was determined as a preliminary investigation prior to invivo efficacy tests. These studies have shown contradictory results where in-vitro studies show no difference in efficacy among different brands as opposed to in-vivo studies. ${ }^{17-19}$ All these researchers have used MIC as the in-vitro testing method and neutropenic mouse thigh infection model as the in-vivo testing method (Table 2). Zuluaga et al ${ }^{17}$ compared the in-vitro efficacy of 19 generics and one innovator product of intravenous gentamicin with the reference powder. Only one generic product demonstrated a statistically significant low level of efficacy in this study. Ten products, including the gentamicin reference powder, showed significantly low efficacy in the invivo testing. According to Vesga et $\mathrm{l}^{18}$ three generics and the innovator product of intravenous vancomycin showed no difference in efficacy in the in-vitro test whereas all three generics failed in-vivo. Only the innovator has shown the expected level of efficacy in the in-vivo testing. Similar observations were made by Rodriguez et $\mathrm{al}^{19}$ when they tested 11 generics and one innovator of oxacillin. No significant difference was observed in the in-vitro test, but all generics failed to achieve innovator's maximum effect in the in-vivo test. These studies highlight the importance of testing the in-vivo efficacy of parenteral antibiotics although this is not required by drug regulatory authorities.

Rodriguez et $\mathrm{al}^{20}$ have compared the in-vitro activity of an innovator and a generic piperacillintazobactam in a study aimed to determine the impact of therapeutically non-equivalent generics on bacterial resistance. Though there was no significant difference in MIC value for both innovator and generic products, therapeutic non-equivalence was observed in the in-vivo assessment and higher enrichment of resistant sub-populations when exposed to the generic products. The same group of researchers have also studied an innovator and five generics of ciprofloxacin. ${ }^{21}$ All those products were identical in pharmaceutical and therapeutic equivalence, in terms of in-vitro activity and in-vivo pharmacodynamics. No differences were observed regarding the magnitude and mechanisms of resistance selection. These two studies have shown that the therapeutic nonequivalence of generics promote antibiotic resistance, whereas generics with equivalent efficacy as efficient as the innovator in preventing resistance.

Three in-vitro studies adopted the agar diffusion test as an alternative to MIC and MBC. These researchers compared the diameters of the zone of inhibition between different brands of antibiotics to determine efficacy. Gunasekaran et $\mathrm{al}^{22}$ tested seven parenteral ceftriaxone brands using this technique. Diluted test antibiotic solutions were added to wells punched in the agar inoculated with the control bacterial strains and allowed to diffuse. Significant difference was not observed in the diameter of the zone of inhibition for different brands and the authors recommended the use of cheaper generic products to reduce the health care cost. Pathak et al and Nkang et al used a different technique where they absorbed the diluted test antibiotics onto filter paper disks which were placed on the inoculated agar. Six products of amoxicillin-clavulanic acid were tested by Pathak et $\mathrm{al}^{23}$ who noted a significantly lesser zone of inhibition for one product against E. coli ATCC 25922. Nkang et $\mathrm{al}^{24}$ used two brands each from ampicillin, 
chloramphenicol, erythromycin, co-trimoxazole and vancomycin to test efficacy. No significant difference was observed in the zone of inhibition of the tested brands. These three studies were conducted in low and middle-income countries (Ethiopia, India and Nigeria). They may have adopted this technique due to the unavailability of resources to carry out MIC and MBC.

The majority of the studies used standard bacterial strains as the test organism to determine efficacy. Fujimura et $\mathrm{al}^{25,26}$ performed two studies using clinical isolates as the test organisms. In one of the studies 80 clinical isolates of MRSA were used to test one innovator and five generics of parenteral vancomycin. ${ }^{25}$ The MIC value of a generic product was higher than that of the other products and the content in each vial also varied between the branded and generic vancomycin products. 147 clinical isolates of MRSA were used to test the efficacy of one innovator and seven generics of teicoplanin. There was no difference in the in-vitro susceptibility between the innovator and the generic products. ${ }^{26}$.

Only a few authors have observed differences in efficacy between various brands of parenteral antibiotics by in-vitro testing methods. Jones et $\mathrm{al}^{27}$ tested 12 generics formulations and one innovator product of piperacillin/tazobactam with four standard bacterial strains. They observed the highest activity with the innovator product, while one generic showed a significantly decreased activity. Zuluaga et $\mathrm{al}^{17}$ have also noted a low level of efficacy in one of 20 pharmaceutically equivalent generics of gentamicin. Other authors have reported similar MIC/MBC values for innovator and generic products and thus concluded that there was no difference in efficacy according to the in-vitro test results.

The majority of published data does not show significant pharmacokinetic differences when invitro and in-vivo efficacy comparisons were done simultaneously. ${ }^{13}$ While the in-vitro efficacy (MIC and MBC) was comparable, the therapeutic efficacy of generic and innovator products showed variability. The pharmaceutical equivalence may not therefore always imply therapeutic equivalence. These results suggest that in-vitro methods may not bet very effective in detecting differences among therapeutically inequivalent generics. 
Table 1: Summary of the in-vitro microbiological studies on parenteral antibiotic efficacy

\begin{tabular}{|c|c|c|c|c|c|}
\hline $\begin{array}{l}\text { Authors \& year } \\
\text { of publication }\end{array}$ & Evaluated antibiotics & Used in-vitro technique & Test organism & Main findings & Comments \\
\hline $\begin{array}{l}\text { Zuluaga et al }{ }^{17} \\
\text { Colombia, 2010 }\end{array}$ & $\begin{array}{l}\text { Innovator product, } 19 \\
\text { generics and the reference } \\
\text { powder of gentamicin }\end{array}$ & MIC by micra brath dilution \& MBC & $\begin{array}{l}\text { Clinically isolated E. caliand Pseudomonas } \\
\text { aeruginosa- ATCC } 27853 \text {, }\end{array}$ & $\begin{array}{l}\text { One generic showed significantly higher MIC and MBC values } \\
\text { whereas all ather gentamicin } \\
\text { generic products were not different to that of the innovator }\end{array}$ & $\begin{array}{l}\text { In-vivo efficacy tests were } \\
\text { also carried out }\end{array}$ \\
\hline $\begin{array}{l}\text { Vesga et al }{ }^{18} \\
\text { Colombia, 2010 }\end{array}$ & $\begin{array}{l}\text { Innavator and } 3 \text { generic } \\
\text { products of vancomycin }\end{array}$ & $\begin{array}{l}\text { MIC by micra brath dilution, MBC \& } \\
\text { Time kill curves }\end{array}$ & $\begin{array}{l}\text { Staphylacaccus auгеus - a clinical isolate and } \\
\text { ATCC 29213 }\end{array}$ & $\begin{array}{l}\text { No difference was observed in MIC, MBC and MIC/MBC ratio } \\
\text { between tested products }\end{array}$ & $\begin{array}{l}\text { In-vivo efficacy tests were } \\
\text { also carried out }\end{array}$ \\
\hline $\begin{array}{l}\text { Rodriguez et al }{ }^{19} \\
\text { Colombia, 2010 }\end{array}$ & $\begin{array}{l}\text { Innovator and } \mathrm{S} \text { generic } \\
\text { products of axacillin }\end{array}$ & MIC by micra brath dilution \& MBᄃ & $\begin{array}{l}\text { Staphy/aсассиs auгеus - a clinical isolate and } \\
\text { ATCC 29213 }\end{array}$ & $\begin{array}{l}\text { There were no differences in the MIC, MВС and MIC/MВГ } \\
\text { ratio in the innovatar and } 9 \text { generic products }\end{array}$ & $\begin{array}{l}\text { In-viva efficacy tests were } \\
\text { alsa carried out }\end{array}$ \\
\hline $\begin{array}{l}\text { Rodriguez et al } \\
\text { Colombia, 2016 }\end{array}$ & $\begin{array}{l}\text { Innovator and four generic } \\
\text { product of piperacillin- } \\
\text { tazobactam }\end{array}$ & $\begin{array}{l}\text { MIC by CLSI method and Janes- } \\
\text { modified arithmetic dilution methad }\end{array}$ & $\begin{array}{l}\text { E. caliATCC 35218, E. cali } 35218 \text { R and E. cali } \\
35218 \Delta \text { bla }\end{array}$ & № significant difference was observed in MIC & $\begin{array}{l}\text { In-vivo efficacy tests were } \\
\text { also carried out }\end{array}$ \\
\hline $\begin{array}{l}\text { Radriguez et al }{ }^{21} \\
\text { Colombia, 2014 }\end{array}$ & $\begin{array}{l}\text { Innavatar and five generics } \\
\text { of ciproflaxacin }\end{array}$ & MIC by micra brath dilution and MBᄃ & Pseudamonas aeruginasa PADI & No significant difference was observed in MIC and MBC & $\begin{array}{l}\text { In-vivo efficacy tests were } \\
\text { also carried out. }\end{array}$ \\
\hline $\begin{array}{l}\text { Gunasekaran et } \\
\text { al }^{22} \\
\text { Ethiopia, 2015 }\end{array}$ & $\begin{array}{l}7 \text { generic products of } \\
\text { ceftriaxane }\end{array}$ & Agar well plate diffusion method & 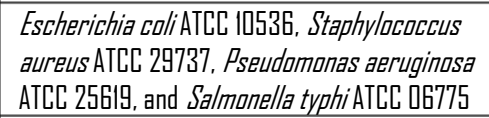 & $\begin{array}{l}\text { No significant difference was observed in the zone of } \\
\text { inhibition far all seven products of ceftriaxone }\end{array}$ & $\begin{array}{l}\text { All generics showed sufficient } \\
\text { inhibitary activity against all } \\
\text { four micruorganisms }\end{array}$ \\
\hline $\begin{array}{l}\text { Pathak et al23 } \\
\text { India, 2016 }\end{array}$ & $\begin{array}{l}\text { I generic and } 5 \text { "brand } \\
\text { preparations" of amaxicillin- } \\
\text { clavulanic acid }\end{array}$ & $\begin{array}{l}\text { Antibiotic impregnated paper disk } \\
\text { diffusion method }\end{array}$ & $\begin{array}{l}\text { Escherichia coliATCᄃ } 25922 \text { and } \\
\text { Staphylacaccus aureus AТСC } 25923\end{array}$ & $\begin{array}{l}\text { One brand has shown a statistically significant less zone of } \\
\text { inhibition compared to ather used products }\end{array}$ & \\
\hline $\begin{array}{l}\text { Nkang et a }{ }^{24} \\
\text { Nigeria, } 2010\end{array}$ & $\begin{array}{l}2 \text { "brand-name" products } \\
\text { each from ampicillin, } \\
\text { chloramphenical, } \\
\text { erythromycin, } \\
\text { cotrimaxazole and } \\
\text { vancomycin were tested }\end{array}$ & $\begin{array}{l}\text { Antibiotic impregnated paper disk } \\
\text { diffusion method }\end{array}$ & $\begin{array}{l}\text { Clinically isolated Escherichia cali, } \\
\text { Staphylocaccus aureus, Pseudamonas } \\
\text { aeruginasa, Klebsiella pneumaniae and } \\
\text { Streptacaccus pyogenes }\end{array}$ & $\begin{array}{l}\text { Significant difference was not observed in the diameter of } \\
\text { the zone of inhibition between test drugs and the standard } \\
\text { antibiatic disks far E. coli, } S \text {. aureus } S \text {. pyogenes. For } P \text {. } \\
\text { aeruginosa, the two brands of ampicillin and erythromycin } \\
\text { and for K. pneumoniaz, the two brands of chloramphenical } \\
\text { and erythramycin were significantly less effective compared } \\
\text { to the standard disks }\end{array}$ & \\
\hline $\begin{array}{l}\text { Fujimura et a| }\left.\right|^{25} \\
\text { Japan, 2008 }\end{array}$ & $\begin{array}{l}\text { I brand and } 5 \text { generic } \\
\text { products of vancomycin }\end{array}$ & МIC by micra brath dilution & $\begin{array}{l}\text { 8D clinical } \\
\text { isolates of MRSA }\end{array}$ & $\begin{array}{l}\text { MIC of ane generic product was slightly higher than the } \\
\text { others }\end{array}$ & $\begin{array}{l}\text { The content of vancomycin per } \\
\text { vial varied from II.D\% to } \\
\text { I03.4\% for generic products. } \\
\text { The generic which produced } \\
\text { the highest MIC accounted for } \\
\text { the lowest content. }\end{array}$ \\
\hline $\begin{array}{l}\text { Fujimura et a| }\left.\right|^{26} \\
\text { Japan, Zall }\end{array}$ & $\begin{array}{l}1 \text { brand and } 7 \text { generic } \\
\text { products of teicaplanin }\end{array}$ & MIC by micra brath dilution & $\begin{array}{l}147 \text { clinical } \\
\text { isolates of MRSA }\end{array}$ & MIL of the brand and all the generic products were similar & $\begin{array}{l}\text { Potency equivalent of each } \\
\text { generic teicoplanin } \\
\text { tended to be lower than that of } \\
\text { the branded drug }\end{array}$ \\
\hline $\begin{array}{l}\text { Jones et a }{ }^{27} \\
\text { USA, } 2008\end{array}$ & $\begin{array}{l}14 \text { generic and I branded } \\
\text { products of Piperacillin } \\
\text { /Tazobactam }\end{array}$ & $\begin{array}{l}\text { MIC by micra brath dilution } \\
\text { SLJID • www. http }\end{array}$ & 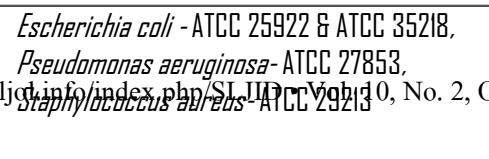 & $\begin{array}{l}\text { One generic product showed equal MIC value to the branded } \\
\text { product. All the ather praducts (22 sampled lots from I3 } \\
\text { oherafofacturers) exhibited decreased activity in MIC that } \\
\text { varied fram the branded product by - } 5 \% \text { to }-35 \%\end{array}$ & $\begin{array}{l}\text { The brandeg (zosyn } \text { (1) } \\
\text { formulation is used as a } \\
\text { reference material to compare } \\
\text { the MIC values }\end{array}$ \\
\hline
\end{tabular}


Table 2 (ct): Summary of the in-vitro microbiological studies on parenteral antibiotic efficacy

\begin{tabular}{|c|c|c|c|c|c|}
\hline $\begin{array}{l}\text { Authors \& year of } \\
\text { publication }\end{array}$ & Evaluated antibiotics & Used in-vitro technique & Test organism & Main findings & Comments \\
\hline $\begin{array}{l}\text { Janes et a }\left.\right|^{27} \\
\text { USA, 2008 }\end{array}$ & $\begin{array}{l}\text { I4 generic and I branded } \\
\text { products of Piperacillin } \\
\text { /Tazobactam }\end{array}$ & MIC by micro brath dilution & 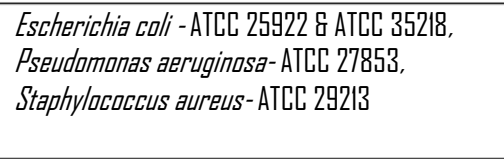 & $\begin{array}{l}\text { One generic product showed equal MIC value to the branded } \\
\text { product. All the other products (22 sampled lots from I3 } \\
\text { manufacturers) exhibited decreased activity in MIC that } \\
\text { varied from the branded praduct by - } 5 \% \text { to - } 35 \%\end{array}$ & $\begin{array}{l}\text { The branded (Zosyn R) } \\
\text { formulation is used as a } \\
\text { reference material to compare } \\
\text { the MIC values }\end{array}$ \\
\hline $\begin{array}{l}\text { Tank et a|28 } \\
\text { India, 20I6 }\end{array}$ & $\begin{array}{l}\text { I generic and } 3 \text { brands of } \\
\text { Ceftazidime }\end{array}$ & $\begin{array}{l}\text { MIC by macro broth dilution } \\
\text { technique and MBC }\end{array}$ & Pseudamanas aeruginasa (АТСС 27853) & $\begin{array}{l}\text { No significant difference in MIC/MBC values of the evaluated } \\
\text { products }\end{array}$ & $\begin{array}{l}\text { Cost of the branded drugs were } \\
\text { approximately } 5 \text { times to } 8 \text { times } \\
\text { higher than the generic product }\end{array}$ \\
\hline $\begin{array}{l}\text { Silva et al }{ }^{29} \\
\text { Colombia, 2010 }\end{array}$ & $\begin{array}{l}\text { Innovatar (MERONEM } \\
\text { TAZOCIN }{ }^{\mathbb{Q}} \text { ), trademark } \\
\text { products and generic } \\
\text { products of Meropenem and } \\
\text { Piperacillin } \\
\text { /Tazobactam available in } \\
\text { Colombia }\end{array}$ & $\begin{array}{l}\text { MIC by micro broth dilution and } \\
\text { MBC, } \\
\text { Critical concentration, } \\
\text { Production of spontaneous } \\
\text { mutation }\end{array}$ & $\begin{array}{l}\text { Acinetabacter baumanii - } 4 \text { strains, } \\
\text { vancomycin-resistant } \\
\text { Enteracaccus gallinarum, Streptocaccus faecalis } \\
\text { ATCC } 29212 \text { and vancomycin- } \\
\text { sensitive strain, E. cali - } 3 \text { strains, } \\
\text { Klebsiella pneumaniae - } 4 \text { strains, }, \text { seudamanas } \\
\text { aeruginosa - } 4 \text { strains, } \\
\text { and Staphylacaccus aureus - } 2 \text { clinical strains \& } \\
\text { ATCC } 25923\end{array}$ & $\begin{array}{l}\text { MIC and MBC results obtained with different } \\
\text { Pathogenic and contral strains showed no differences } \\
\text { among samples, } \\
\text { No significant difference in critical concentration among } \\
\text { samples, } \\
\text { All the } \\
\text { samples behaved similarly in spontaneous mutant production }\end{array}$ & $\begin{array}{l}\text { All the evaluated generic } \\
\text { products have fulfilled the } \\
\text { requirements to be considered } \\
\text { for clinical use }\end{array}$ \\
\hline $\begin{array}{l}\text { Diaz et al }{ }^{30} \\
\text { Colambia, 2011 }\end{array}$ & $\begin{array}{l}\text { Trademarked and generic } \\
\text { products of vancomycin } \\
\text { available in Colombia }\end{array}$ & $\begin{array}{l}\text { MIC bymicro brath dilution and MBC, } \\
\text { Critical concentration, } \\
\text { Production of spontaneaus } \\
\text { mutation }\end{array}$ & 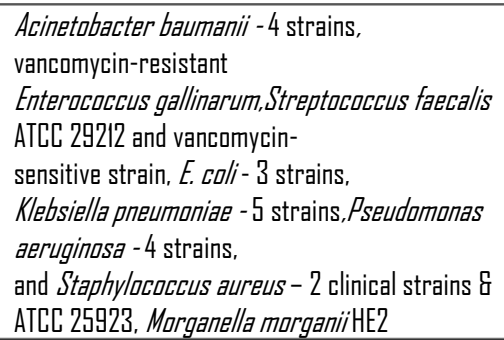 & $\begin{array}{l}\text { No significant difference was observed in MIГ, МВГ, Critical } \\
\text { concentration and in the spontaneous mutant production }\end{array}$ & $\begin{array}{l}\text { All the evaluated generic } \\
\text { products have fulfilled the } \\
\text { requirements to be considered } \\
\text { for clinical use }\end{array}$ \\
\hline $\begin{array}{l}\text { Moet et al } \\
\text { USA, } 2009\end{array}$ & $\begin{array}{l}14 \text { genericproducts of } \\
\text { Piperacillin } \\
\text { /Tazobactam }\end{array}$ & МIC by micга brath dilution & 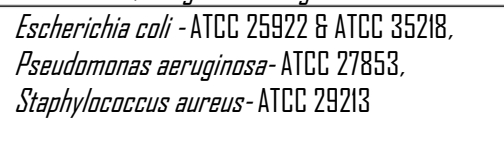 & $\begin{array}{l}2 \text { generics showed MIC values greater than the branded } \\
\text { praduct. Other products (23 sampled lats fram } 14 \\
\text { manufacturers) exhibited decreased activity in MIC that } \\
\text { varied fram the branded praduct by - } 3 \% \text { to - } 42 \%\end{array}$ & $\begin{array}{l}\text { This study was performed to } \\
\text { expand the findings of Jones et } \\
\text { al }^{27} \text { and has used } 14 \text { generics that } \\
\text { were not studied by Jones et al. }\end{array}$ \\
\hline $\begin{array}{l}\text { Naimi et a }\left.\right|^{32} \\
\text { Afghanistan, 2016 }\end{array}$ & $\begin{array}{l}40 \text { generic products of } \\
\text { ceftriaxone }\end{array}$ & MBC & Staphy/aсассия аигеиs-АТСС Z9Z1З & $\begin{array}{l}\text { MBC difference among the products were not statistically } \\
\text { significant }\end{array}$ & $\begin{array}{l}\text { Efficacy had no relationship with } \\
\text { the price of the product }\end{array}$ \\
\hline
\end{tabular}

Abbreviations: MIC, Minimal Inhibitory Concentration; MBC, Minimal Bactericidal Concentration; ATCC, American Type Culture Collection 
Table 3: Summary of the studies where the efficacy is assessed by both in-vitro and in-vivo techniques

\begin{tabular}{|c|c|c|c|c|c|}
\hline Authors \& year of publication & $\begin{array}{l}\text { Tested antibiotic/s and test } \\
\text { organism/s }\end{array}$ & $\begin{array}{l}\text { Used in-vitro \& in-vivo } \\
\text { techniques }\end{array}$ & Main in-vitro finding & Main in-vivo finding & Comment \\
\hline Zuluaga et al ${ }^{17}, 2010$ & $\begin{array}{l}\text { Gentamicin - innovatar, } 19 \\
\text { generics \& the reference powder } \\
\text { Test organism: } \\
\text { E. coli-clinical isolate } \\
\text { P. aeruginasa ATCC 27853 }\end{array}$ & $\begin{array}{l}\text { In-vitra: } \\
\text { MIC \& MВГ } \\
\text { In-viva: } \\
\text { neutrapenic mouse thigh infection } \\
\text { model }\end{array}$ & $\begin{array}{l}\text { Only one generic showed } \\
\text { significantly higher MIC and MBC } \\
\text { (lower efficacy) compared with the } \\
\text { innavatar }\end{array}$ & $\begin{array}{l}\text { Reference powder \& nine generics } \\
\text { displayed significantly lower } \\
\text { efficacy from the innavator }\end{array}$ & $\begin{array}{l}\text { Reference powder \& eight generics failed } \\
\text { in-vivo despite being equivalent by in-vitro } \\
\text { methods }\end{array}$ \\
\hline Vesga et al8, 2010 & $\begin{array}{l}\text { Vancamycin - innavatar \& three } \\
\text { generics } \\
\text { Test arganism: } \\
\text { S. aureus - a clinical isolate and } \\
\text { ATCC } 29213\end{array}$ & $\begin{array}{l}\text { In-vitra: } \\
\text { MIL, MBC \& } \\
\text { time-kill curves (ТКГ) } \\
\text { In-viva: } \\
\text { neutrapenic mouse thigh infection } \\
\text { madel }\end{array}$ & $\begin{array}{l}\text { Vancomycin products did not differ } \\
\text { in MIC, MBC, MBᄃ/MIГ and TKᄃ }\end{array}$ & $\begin{array}{l}\text { Only the innavatar displayed the } \\
\text { expected bactericidal efficacy } \\
\text { (maximum antibacterial effect - } \\
\text { Emax) }\end{array}$ & $\begin{array}{l}\text { All generics failed in-viva despite being } \\
\text { equivalent by in-vitro methads }\end{array}$ \\
\hline Radriguez et al ${ }^{19}$, 2010 & $\begin{array}{l}\text { Oxacillin - innavatar \& Il generics } \\
\text { Test organism: } \\
\text { S. aureus - a clinical isolate and } \\
\text { ATCC 29213 }\end{array}$ & $\begin{array}{l}\text { In-vitra: } \\
\text { MIC \& MBᄃ } \\
\text { In-viva: } \\
\text { neutrapenic mouse thigh infection } \\
\text { madel } \\
\end{array}$ & $\begin{array}{l}\text { Dnly } 9 \text { generics \& the innovator } \\
\text { were tested in-vitro. No } \\
\text { differences were observed. }\end{array}$ & $\begin{array}{l}\text { All generics (n=II) failed to } \\
\text { demonstrate therapeutic } \\
\text { equivalence with the innovator }\end{array}$ & $\begin{array}{l}\text { Microbiological assay was done to } \\
\text { determine the concentration of active } \\
\text { pharmaceutical ingredient of innovator } 8 \text { g } \\
\text { generics. Four generics did differ in } \\
\text { patency. }\end{array}$ \\
\hline Radriguez et al ${ }^{20}, 2016$ & $\begin{array}{l}\text { Piperacillin- tazobactam - } \\
\text { innavatar \& } 4 \text { generics } \\
\text { Test organism: } \\
\text { E. caliATCC 35218, 35218R and } \\
\text { 35218Dbla }\end{array}$ & $\begin{array}{l}\text { In-vitra: } \\
\text { MIC } \\
\text { In-viva: } \\
\text { neutrapenic mouse thigh infection } \\
\text { madel. }\end{array}$ & No difference was abserved in MIC & $\begin{array}{l}\text { Only two generics and the } \\
\text { innovator were tested in-viva. One } \\
\text { generic failed to demonstrate } \\
\text { therapeutic equivalence with the } \\
\text { innovator }\end{array}$ & $\begin{array}{l}\text { Further tests were done with the failed } \\
\text { generic to determine the selection of } \\
\text { resistant bacterial sub-populations. The } \\
\text { generic amplified the resistant sub- } \\
\text { population up to 20-times compared with } \\
\text { the innovator. }\end{array}$ \\
\hline Radriguez et al21, 2014 & $\begin{array}{l}\text { Ciproflaxacin - Innovatar and five } \\
\text { generics } \\
\text { Test organism: } \\
\text { P. aeruginasa ATCC } 27853 \text { g } \\
\text { clinical strain }\end{array}$ & $\begin{array}{l}\text { In-vitra: } \\
\text { MIC \& MBᄃ } \\
\text { In-viva: } \\
\text { neutrapenic mouse thigh infection } \\
\text { model. }\end{array}$ & $\begin{array}{l}\text { There were no differences in the } \\
\text { MIC or MBC for all products. }\end{array}$ & $\begin{array}{l}\text { No difference in therapeutic } \\
\text { equivalence with the innavatar }\end{array}$ & $\begin{array}{l}\text { Selection of resistant bacterial sub- } \\
\text { populations were same magnitude for the } \\
\text { innovator \& generics. }\end{array}$ \\
\hline
\end{tabular}




\section{Conclusion}

It is important to maintain both pharmaceutical equivalence and bioequivalence between innovator products and their generics. Eleven of the sixteen studies in this review (68.8\%) have shown no significant differences in the efficacy between generic and innovator antibiotics. However, in studies where in-vivo and in-vitro tests were done simultaneously on the same drugs, significant differences in efficacy were observed with in-vivo results. This is probably because the different brands were pharmaceutically equivalent, but not therapeutically equivalent. Thus the implication of in-vitro results alone to determine the efficacy of parenteral antibiotics may not yield optimum results. In-vitro methods such as MIC and MBC can be applied as a preliminary tool in the efficacy assessment. In low-income countries where optimal laboratory facilities are not available, in-vitro efficacy testing will serve as a presumptive method to identify sub-optimal generic parenteral antibiotics. Since the literature shows a discrepancy between in-vitro and in-vivo efficacy of different brands of parenteral antibiotics, policy makers in these countries should strive to implement in-vivo efficacy testing as a more standard tool for drug efficacy evaluation.

\section{References}

1. Klein EY, Van Boeckel TP, Martinez EM et al. Global increase and geographic convergence in antibiotic consumption between 2000 and 2015. Proc Natl Acad Sci USA 2018; 115(15): E3463E3470. doi.org/10.1073/pnas.1717295115

2. Generic Drugs - Generic Drug Facts. Available at: https://www.fda.gov/drugs/resourcesforyou/consumers/buyingusingmedicinesafely/generi288 cdrugs/ucm167991.html accessed on 27.7.2018

3. Jensen US, Muller A, Brandt CT et al. Effect of generics on price and consumption of ciprofloxacin in primary healthcare: The relationship to increasing resistance. J Antimicrob Chemother 2010; 65(6):1286-91. doi: 10.1093/jac/dkq093

4. National medicines regulatory authority act - Sri Lanka: Parliament of the Democratic Socialist Republic of Sri Lanka; Act no.5 2015; p. 0-97

5. U.S. Food and Drug Administration. Code of Federal Regulations Title 21CFR314.3 296.: Available at : https://www.accessdata.fda.gov/scripts/cdrh/cfdocs/cfcfr/CFRSearch.cfm? fr=314.3 accessed on 30.7.2018

6. Shrank WH, Liberman JN, Fischer MA et al. Physician perceptions about generic drugs. Ann Pharmacother 2011; 45(1):31-8. doi: 10.1345/aph.1P389

7. Gallelli L, Mumoli L, Palleria $\mathrm{C}$ et al. Safety and efficacy of generic drugs with respect to brand formulation. J Pharmacol Pharmacother 2013; 4(5):S110-114

8. Rodriguez CA, Agudelo M, Cataño JC et al. Potential therapeutic failure of generic vancomycin in a liver transplant patient with MRSA peritonitis and bacteremia. J Infect2009; 59(4):277-80. doi: 10.1016/j.jinf.2009.08.005

9. Rodriguez CA, Agudelo M, Zuluaga AF et al. Generic vancomycin enriches resistant subpopulations of Staphylococcus aureus after exposure in a neutropenic mouse thighinfection model. Antimicrob Agents Chemother 2012; 56(1):243-7. doi: 10.1128/AAC.05129-11

10. Kaier K, Frank U, Meyer E. Economic incentives for the (over-)prescription of broad-spectrum antimicrobials in German ambulatory care. J Antimicrob Chemother 2011; 66(7):1656-8. doi.org/10.1093/jac/dkr134

11. World Health Organization. Multisource (generic) pharmaceutical products: guidelines on registration requirements to establish interchangeability. WHO Technical Report Series, No 1003, 2017; Annex 6 Available at http://apps.who.int/medicinedocs/documents/s23245en/s23245en.pdf 
accessed on 6.7.2018

12. U.S Food and Drug Administration. Code of Federal Regulations Title 21CFR320.22 Available at $h t t p s: / / w w w . a c c e s s d a t a . f d a . g o v / s c r i p t s / c d r h / c f d o c s / c f c f r / C F R S e a r c h . c f m ? f r=320.22$ accessed on 30.7.18

13. Tattevin $\mathrm{P}$, Crémieux AC, Rabaud $\mathrm{C}$ et al. Efficacy and quality of antibacterial generic products approved for human use: A systematic review. Clin Infect Dis. 2014; 58(4):458-69. doi: $10.1093 / \mathrm{cid} / \mathrm{cit} 769$

14. Welage LS, Kirking DM, Ascione FJ et al. Understanding the scientific issues embedded in the generic drug approval process. J Am Pharm Assoc (Wash) 2001; 41(6):856-67. doi.org/10.1016/S1086-5802(16)31327-4

15. CLSI. Methods for dilution antimicrobial susceptibility tests for bacteria that grow aerobically; approved standard -10th ed. CLSI document M07 - A10. Wayne PA: Clinical and Laboratory Standards Institute; 2015

16. CLSI. Methods for determining bactericidal activity of antimicrobial agents; approved guideline. CLSI document M 26A. Wayne PA: Clinical and Laboratory Standards Institute; 1999.

17. Zuluaga AF, Agudelo M, Cardeño JJ et al. Determination of therapeutic equivalence of generic products of gentamicin in the neutropenic mouse thigh infection model. PLoS One 2010; 20; 5(5):e10744. doi: 10.1371/journal.pone.0010744

18. Vesga O, Agudelo M, Salazar BE et al. Generic vancomycin products fail in vivo despite being pharmaceutical equivalents of the innovator. Antimicrob Agents Chemother. 2010; 54(8):32719. doi: 10.1128/AAC.01044-09

19. Rodriguez CA, Agudelo M, Zuluaga AF et al. In vitro and in vivo comparison of the antistaphylococcal efficacy of generic products and the innovator of oxacillin. BMC Infect Dis. 2010; 10:153. doi: $10.1186 / 1471-2334-10-153$

20. Rodriguez CA, Agudelo M, Aguilar YA et al. Impact on bacterial resistance of therapeutically nonequivalent generics : The case of piperacillin-tazobactam. PLoS One. 2016; 11(5):e0155806. doi: 10.1371/journal.pone.0155806

21. Rodriguez CA, Agudelo M. Impact on resistance of the use of therapeutically equivalent generics : the case of ciprofloxacin. Antimicrob Agents Chemother. 2015; 59:53-8. doi: 10.1128/AAC.03633-14

22. Gunasekaran T, Desta ED, Seifu MF et al. Comparative efficacy evaluation of seven commercial injectable ceftriaxone purchased at Ambo, Oromia Regional State, Ethiopia, using agar well plate diffusion method. J Pharm Heal Serv Res. 2015; 6:97-101.doi.org/10.1111/jphs. 12095

23. Pathak P, Dawane J. In vitro comparison of generic and branded preparations of amoxicillin with potassium clavulanate. J Clin Diagnostic Res. 2016; 10(9):FC07-9 doi: 10.7860/JCDR/2016/20009.8466

24. Nkang AO, Okonko IO, Lennox JA et al. Survey of the efficacy and quality of some brands of the antibiotics sold in calabar metropolis, south-south region of Nigeria. Sci Res Essays. 2010; 5(4):395-406. No doi

25. Fujimura S, Watanabe A, Fuse K et al. In vitro susceptibility of clinical isolates of methicillin resistant Staphylococcus aureus (MRSA) to manufactured generic drugs compared with the brand vancomycin. Int J Antimicrob Agents. 2008; 31:391-2. doi: http://dx.doi.org/10.1016/j.ijantimicag.2008.01.002

26. Fujimura S, Fuse K, Takane $\mathrm{H}$ et al. Antibacterial effects of brand-name teicoplanin and generic products against clinical isolates of methicillin-resistant Staphylococcus aureus. J Infect Chemother. 2011; 17(1):30-3. doi: 10.1007/s10156-010-0094-0

27. Jones RN, Fritsche TR, Moet GJ. In vitro potency evaluations of various piperacillin/ tazobactam generic products compared with the contemporary branded (Zosyn $®$, Wyeth) formulation. Diagn Microbiol Infect Dis. 2008; 61(1):76-9. doi:10.1016/j.diagmicrobio.2007.12.010.

28. Tank ND, Bhansali NB, Karelia BN. In vitro comparison of generic and branded 
formulations of ceftazidime using standard strain of Pseudomonas. Natl J Integr Res Med. 2016; 7(2):31-6. No doi

29. Silva E, Díaz JA, Arias MJ et al. Comparative in vitro study of the antimicrobial activities of different commercial antibiotic products for intravenous administration. BMC Clin Pharmacol. 2010; 10:3. doi:10.1186/1472-6904-10-3

30. Diaz JA, Silva E, Arias MJ et al. Comparative in vitro study of the antimicrobial activities of different commercial antibiotic products of vancomycin. BMC Clin Pharmacol. 2011; 11(9). doi: 10.1186/1472-6904-11-9

31. Moet GJ, Watters AA, Sader HS et al. Expanded studies of piperacillin/tazobactam formulations: variations among branded product lots and assessment of 46 generic lots. Diagn Microbiol Infect Dis . 2009; 65(3):319-22. doi: 10.1016/j.diagmicrobio.2009.06.012

32. Naimi HM, Rasekh H, Haem Rahimi M et al. Assessment of the price-efficacy relationship for multiple brands of ceftriaxone sodium in Kabul: A cross-sectional study BMC Res Notes. 2016; 9:86. doi.org/10.1186/s13104-016-1904-y 